\title{
PERLINDUNGAN HUKUM PEMBELI KENDARAAN DALAM PERJANJIAN PEMBIAYAAN KONSUMEN DAN PELAKSANAAN EKSEKUSI JAMINAN FIDUSIA
}

\author{
Oleh: \\ Rustan $^{1}$, Sahban $^{2}$, dan Andi Risma ${ }^{3}$ \\ 1,2, ${ }^{3}$ Fakultas Hukum Universitas Muslim Indonesia, Makassar \\ ${ }^{1}$ rustanadil@umi.ac.id
}

\begin{abstract}
ABSTRAK: Kebutuhan manusia saat ini semakin beragam dan berbagai bentuk perjanjian menjadi pilihan antara lain penjanjian jaminan fidusia. Bilamana pihak pemberi fidusia (konsumen) melakukan wanprestasi atau tidak tertib dan tidak lancar memenuhi kewajiban angsuran utangnya kepada penerima fidusia (pelaku usaha), maka pelaku usaha dapat melaksanakan eksekusi sendiri atas objek jaminan fidusia yang berada dalam kekuasaan pemberi fidusia. Proses eksekusi objek jaminan fidusia yang seringkali menimbulkan permasalahan sehingga dilakukan uji materi ke Mahkamah Konstitusi sehingga lahir Putusan Mahkamah Konstitusi No.18/PUU-XVII/2019 tanggal 06 Januari 2020. Penelitian bertujuan untuk memperoleh gambaran mengenai perlindungan hukum pembeli kendaraan dengan klausula perjanjian baku dalam pembiayaan konsumen dan pelaksanaan eksekusi jaminan fidusia menurut undang-undang dan Putusan Mahkamah Konstitusi No.18/PUU-XVII/2019 tanggal 06 Januari 2020. Penelitian menunjukkan klausula yang disiapkan pelaku usaha dalam bentuk perjanjian baku menjadikan konsumen wajib mengikuti keinginan pelaku usaha, bahkan terdapat kecenderungan hakhak konsumen yang sudah tegas diatur dalam peraturan perundang-undangan diabaikan pelaku usaha. Pelaksanaan eksekusi atas objek jaminan fidusia yang diatur dalam berbagai peraturan perundang-undangan belum dilaksanakan secara konsisten dan masih mengandalkan keinginan pelaku usaha dengan menggunakan petugas eksternal. Setelah Putusan Mahkamah Konstitusi No. 18/PUU-XVII/2019 tanggal 06 Januari 2020, sekalipun kaidah yang terdapat dalam Pasal 15 ayat (2) dan ayat (3) Undang-undang No. 42 Tahun 1999 tentang Jaminan Fidusia diubah dengan menghargai konsumen, namun dalam kenyataannya masih terjadi pengambilan/penarikan kendaraan secara paksa. Pelaksanaan eksekusi dalam Putusan MK tersebut mempersyaratkan jika pemberi fidusia (konsumen) enggan menyerahkan objek jaminan fidusia, maka pelaku usaha mengajukan permohonan eksekusi ke pengadilan seperti layaknya eksekusi putusan pengadilan pada umumnya. Terdapat jumlah permohonan eksekusi jaminan fidusia ke pengadilan.
\end{abstract}

KATA KUNCI: Eksekusi, jaminan fidusia, perlindungan hukum

\begin{abstract}
Human needs today are increasingly diverse and various forms of agreements become an option, among others, the binding of fiduciary guarantees. If the fiduciary (consumer) defaults or is not disciplined and does not smoothly fulfill its debt installment obligations to the fiduciary (business actor), then the businessman can carry out his own execution on the object of fiduciary guarantee that is within the power of the fiduciary. The process of execution of fiduciary guarantee objects that often cause problems so that material tests are conducted to the Constitutional Court so that the Decision of the Constitutional Court No.18/PUU-XVII/2019 was born on January 06, 2020. The research aims to obtain an overview of the legal protection of vehicle buyers
\end{abstract}


with standard agreement clauses in consumer financing and the execution of fiduciary guarantees according to the law and the Decision of the Constitutional Court No.18/PUUXVII/2019 dated January 6, 2020. Research shows that clauses prepared by businesses in the form of standard agreements make consumers obliged to follow the wishes of businesses, there is even a tendency for consumer rights that have been expressly regulated in the legislation ignored by businesses. The execution of fiduciary guarantee objects stipulated in various laws and regulations has not been carried out consistently and still relies on the wishes of businesses using external officers. After the Decision of the Constitutional Court No. 18/PUU-XVII/2019 dated January 6, 2020, even though the rules contained in Article 15 paragraph (2) and paragraph (3) of Law No. 42 of 1999 on Fiduciary Guarantees are changed with respect to consumers, but in reality there is still a forced taking / withdrawal of vehicles. The execution in the Court's Decision requires that if the fiduciary (consumer) is reluctant to submit the object of fiduciary guarantee, then the businessman submits an application for execution to the court as it is like the execution of a court ruling in general. There are a number of requests for the execution of fiduciary bail to the court.

KEYWORDS: Execution, fiduciary guarantee, legal protection

\section{PENDAHULUAN}

Kehidupan manusia selalu mengalami perubahan sejalan dengan perkembangan dan peningkatan taraf hidup masyarakat. Bagi manusia, memenuhi kebutuhan hidup yang semakin beragam dilakukan dengan berbagai bentuk atau metode yang saling menguntungkan antara penjual dan pembeli.Namun kedudukan pembeli atau konsumen yang senantiasa berada dalam posisi tawar yang lemah, mengakibatkan dominasi pelaku usaha, termasuk klausula yang dimuat dalam perjanjian jual beli kendaraan dikenal dengan standar contract.

Apakah pihak pembeli atau konsumen merasakan adanya dominasi pihak pelaku usaha dalam transaksi yang dilakukan dalam proses jual beli kendaraan dengan mencicil? Pembeli yang lalai membaca dan mencermati setiap klausula yang sudah dimuat dalam perjanjian pembiayaan tersebut bukanlah menjadi alasan pelaku usaha untuk tidak merealisasikan setiap klausula dalam perjanjian baku. Secara logika, kemudahan untuk membuat perjanjian yang secara sepihak dipersiapkan oleh pelaku usaha dan bersifat massal akan lebih memudahkan dan pembeli kendaraan akan mengalami tekanan yang dilakukan pelaku usaha (lembaga pembiayaan) untuk merealisasikan perjanjian baku.

Penarikan kendaraan yang dilakukan pelaku usaha berimplikasi berat bagi pembeli oleh karena pelaku usaha menggunakan berbagai macam cara untuk menguasai objek jaminan fidusia bilamana pembeli kurang lancar membayar angsuran cicilan. Dalam hal ini jebakan demi jebakan yang sudah disiapkan pelaku usaha akan mematikan langkah pembeli untuk mempertahankan objek jaminan fidusia yang sudah dibeli dan dikuasainya selama ini. Padahal berbagai upaya yang dilakukan pemerintah untuk melindungi kesewenang-wenangan pelaku usaha antara lain dengan Peraturan Kapolri No. 8 Tahun 2011 tentang Pengamanan Eksekusi Jaminan Fidusia yang mengatur mekanisme pengamanan saat pelaksanaan eksekusi jaminan fidusia 
dari tangan pembeli. Tujuan Peraturan Kapolri tersebut diuraikan dalam Pasal 2 yaitu (a) Terselenggaranya pelaksanaan eksekusi Jaminan Fidusia secara aman, tertib, lancar, dan dapat dipertanggungjawabkan, dan (b) Terlindunginya keselamatan dan keamanan Penerima Jaminan Fidusia, Pemberi Jaminan Fidusia dan/atau masyarakat dari perbuatan yang dapat menimbulkan kerugian harta benda dan/atau keselamatan jiwa.

Melihat dan mencermati berbagai akibat hukum yang timbul dari pelaksanaan eksekusi Jaminan Fidusia, maka kepastian hukum yang diharapkan masyarakat mengenai mekanisme pelaksanaan eksekusi jaminan fidusia semakin jelas dengan lahirnya Putusan Mahkamah Konstitusi No.18/PUUXVII/2019 tanggal 6 Januari 2020.

Putusan Mahkamah Konstitusi tersebut seharusnya menjadi pedoman dalam melaksanakan dan mewujudkan hak-hak Penerima Fidusia (kreditur) oleh karena secara langsung mengikat seluruh pihak yang berhubungan dengan perjanjian dengan Jaminan fidusia, baik pemberi fidusia, penerima fidusia, maupun pihak yang seringkali disebut pihak ketiga (eksternal) yang seringkali melakukan eksekusi atau penarikan kendaraan yang menjadi jaminan fidusia dan menimbulkan kontroversi.

\section{METODE PENELITIAN}

Penelitian hukum dengan pendekatan sosio-yuridis yaitu yang memandang hukum bukan saja sebagai seperangkat kaidah yang bersifat normatif (law in books), tetapi juga melihat bagaimana hukum berinteraksi dengan masyarakat (law in action).

Berdasarkan hal tersebut, maka dalam penelitian ini peneliti akan menggunakan metode penelitian kualitatif, yang diharapkan dapat ditemukan makna-makna yang tersembunyi dibalik permasalahan sebagai obyek yang akan diteliti. Metode kualitatif berusaha memahami persoalan secara keseluruhan (holistik) dan dapat mengungkapkan rahasia dan makna tertentu.

Pendekatan kualitatif digunakan oleh karena sesuai dengan informasi dari hasil studi kepustakaan dan wawancara, hasilnya akan dianalisis dengan mengacu pada rumusan masalah dalam penelitian untuk selanjutnya dilakukan korespondensi mengenai hal yang berkaitan dengan objek kajian penelitian.

Data yang diperlukan dalam penelitian ini, akan dikumpulkan melalui studi kepustakaan (library research), kuesioner, dan wawancara dengan informan pada instansi terkait. Pendekatan yang digunakan, maka dalam penelitian ini analisis yang digunakan adalah pendekatan doktrinal, analisis dilakukan dengan menggunakan metode analisis kualitatif. Menganalisis data yang dikumpulkan dari pelaksanaan wawancara untuk mengkorelasikan berbagai ketentuan yang berlaku dengan penjelasan yang disampaikan responden.

\section{HASIL DAN PEMBAHASAN}

\section{Analisis Hukum Mengenai Isi Perjanjian Pembiayaan Konsumen}

Perjanjian baku (standard contract) dibuat secara cermat dan rapi oleh pelaku usaha yang substansinya memproteksi berbagai kepentingan ataupun hak-hak yang berpotensi melahirkan kerugian. Selain itu dalam berbagai pasal yang dimuat dalam perjanjian baku, pelaku usaha sengaja mengaburkan atau tidak memberikan kepastian hukum mengenai hak-hak konsumen. Oleh karena itu pelaku usaha sengaja membuat klausula yang menguntungkan dirinya dan dilain pihak 
mengaburkan atau tidak menjelaskan hak-hak konsumen yang sudah jelas diatur dalam Peraturan Otoritas Jasa Keuangan Republik Indonesia No.35/POJK.5/2018 tentang Penyelenggaraan Usaha Perusahaan Pembiayaan.

Analisis beberapa pasal yang dimuat dalam perjanjian pembiayaan konsumen yang berpotensi merugikan pembeli kendaraan (konsumen) yang menunjukkan diabaikannya perlindungan hukum terhadap konsumen.

\section{a. Kewajiban Tambahan Konsumen yang Bertikad Baik}

PT. Nissan Financial Services Indonesia sebagai perusahaan pembiayaan dalam perjanjian baku yang disiapkan untuk disetujui dan ditandatangani konsumen memuat ketentuan, "pelunasan utang dipercepat dikenakan biaya administrasi 10\% dari sisa utang pokok yang akan dibayar, jika pelunasan dilakukan dan telah dibayar paling banyak enam kali angsuran". Dalam ayat selanjutnya dijelaskan, "jika sudah melewati angsuran pembayaran enam kali dan dilakukan pelunasan, maka dikenakan biaya administrasi 5\% dari sisa utang pokok yang akan dibayar".

\section{b. Keterlambatan Pengambilan BPKB oleh Konsumen}

Kewajiban pelaku usaha agar menyimpan dan mengamankan bukti kepemilikan atas agunan atau dokumen objek jaminan menjadi hal yang mutlak, sebab dokumen tersebut berada dalam kekuasaan pelaku usaha dan seharusnya memberikan jaminan kepastian kepada konsumen bahwa dokumen objek jaminan tersebut dalam keadaan aman. Oleh karena itu salah satu kewajiban perusahaan pembiayaan adalah menyimpan BPKB tersebut. Hal ini diatur dalam Pasal 43 Peraturan Otoritas Jasa Keuangan Republik Indonesia (POJK-
RI) No.35/POJK.5/2018 tentang Penyelenggaraan Usaha Perusahaan Pembiayaan, yakni: (1) Dalam hal Perusahaan Pembiayaan menyalurkan Pembiayaan yang sumber dananya berasal selain dari kerja sama pembiayaan penerusan (channeling) dan/atau pembiayaan bersama (joint financing), Perusahaan Pembiayaan wajib menyimpan dan memelihara dokumen bukti kepemilikan atas agunan pada kantor pusat dan/atau kantor cabang Perusahaan Pembiayaan sampai dengan perjanjian pembiayaan berakhir. (2) Perusahaan Pembiayaan wajib memiliki pedoman tertulis dalam melakukan penyimpanan dan pemeliharaan bukti kepemilikan atas agunan.

PT. Sinar Mas Multifinance memuat klausula pada Pasal 3 angka 9 Perjanjian Pembiayaan Konsumen dan Pemberian Jaminan Secara Kepercayaan (Fidusia), yakni "Jika BPKB tidak diambil setelah tiga hari pelunasan, maka dibitur dikenakan denda Rp 50.000 (lima puluh ribu rupiah) setiap bulan".

\section{c. Pengabaian Surat Peringatan terhadap Konsumen yang Wanprestasi}

Perjanjian pembiayaan konsumen yang disiapkan PT. Oto Multiartha sebagai pelaku usaha. Pasal 10 perjanjian tersebut dimuat ketentuan, "alasan debitur cidera janji tidak perlu didahului dengan peringatan khusus atau suatu penetapan dari pengadilan, melainkan cukup terbukti". Ketentuan ini menunjukkan klausula yang dibuat oleh pelaku usaha dalam perjanjian pembiayaan mengancam kedudukan pembeli kendaraan atau debitur, sebab tidak perlu ada peringatan atau teguran dari pelaku usaha jika konsumen cidera janji dalam melakukan pembayaran angsuran.

Klausula tersebut bertentangan dengan ketentuan Pasal 47 Peraturan 
Otoritas Jasa Keuangan Republik Indonesia

No.35/POJK.5/2018 (POJK-RI) tentang

Penyelenggaraan Usaha Perusahaan Pembiayaan. Adapun ketentuan tersebut mengatur: (1) Dalam hal Debitur wanprestasi PerusahaanPembiayaan wajib melakukan penagihan, paling sedikit dengan memberikan surat peringatan sesuai dengan jangka waktu dalam perjanjian pembiayaan. (2) Surat peringatan sebagaimana dimaksud pada ayat (1) wajib paling sedikit memuat informasi mengenai: (a) Jumlah hari keterlambatan pembayaran kewajiban; (b) outstanding pokok terutang; (c) bunga yang terutang; dan (d) denda yang terutang.

\section{d. Pelunasan Seluruh Hutang Sekaligus dan Seketika Jika Dua Bulan Menunggak}

Perjanjian pembiayaan PT. Bussan Auto Finance (BAF), pada Pasal 8 ayat (2) huruf a, mengatur, "Apabila kreditur telah memberikan surat peringatan sebanyak dua kali kepada kreditur, maka seluruh jumlah utang yang masih belum dibayar oleh debitur menjadi jatuh tempo dan harus segera dibayar seketika sekaligus beserta denda (jika ada) termasuk semua biaya/kerugian yang diderita oleh kreditur".

\section{e. Itikad Buruk Pelaku Usaha Atas Sisa Hasil Penjualan Objek Jaminan}

Hakikat pelelangan objek jaminan dalam hukum jaminan adalah sematamata untuk menutupi kewajiban debitur, bukan serta merta objek jaminan menjadi milik kreditur, sehingga seluruh harga jual kendaraan menjadi hak perusahaan pembiayaan.

Dalam hal ini pelaku usaha sengaja tidak mengungkap hal-hal yang krusial dalam lembaga jaminan, yakni hasil pelelangan objek jaminan hanyalah sekadar untuk melunasi jumlah hutang konsumen. Tidak adanya transparansi klausula tentang sisa harga pelelangan setelah dikurangi dengan pelunasan utang debitur merupakan tindakan yang merugikan konsumen.

\section{Pelaksanaan Eksekusi Jaminan Fidusia Menurut Undang-undang dan Putusan Mahkamah Konstitusi No.18/PUU-XVII/2019 tanggal 06 Januari 2020}

Dalam proses eksekusi objek jaminan fidusia terdapat beberapa kendala sekalipun hal itu sudah tegas diatur dalam UU Jaminan Fidusia. Kendala yang sering terjadi sejak terjadinya wanprestasi debitur dalam memenuhi prestasinya antara lain adalah pada umumnya: (1) Lembaga Jaminan Fidusia merupakan pengalihan hak kepemilikan suatu bendaatas dasar kepercayaan, sehingga benda yang hak kepemilikannya dialihkantersebut tetap dalam penguasaan pemilik benda. Dengan demikian akibatpenguasaan secara phisik benda berada pada Pemberi Fidusia, maka pada saatakan dilakukan eksekusi kadangkala objek Jaminan Fidusia telah rusak atauhilang atau berpindahtangan dan hal inilah yang menjadi salah satu kendala; (2) Selain itu Jaminan Fidusia sebagai bentuk lembaga jaminan yang diatur dalamUU No. 42 tahun 1999 belum mengakomodasi secara lengkap dan komprehensifpada pelaksanaan hak eksekutorial oleh penerima Fidusia dilapangan; (3) Nilai barang jaminan fidusia tidak sesuai lagi karena sudah rusak, tidak dipeliharadebitur dengan semestinya, sehingga menimbulkan kerugian bagi bank; (4) Khusus objek jaminan fidusia berupa stock/persediaan barang, peralatan(inventaris), perabotan, mesinmesin sudah dipindahtangankan oleh debiturtanpa sepengetahuan bank; (5) 
Sita eksekutorial yang langsung dapat dilakukan dalam eksekusi jaminan fidusia,dalam praktek oleh petugas KP2LN masih harus dimintakan penetapanpengadilan ${ }^{1}$.

Eksekusi atas objek jaminan fidusia telah menimbulkan permasalahan di tengah masyarakat. Pelaku usaha yang seringkali menggunakan jasa eksternal untuk menarik objek jaminan secara paksa dari kekuasaan konsumen merupakan hal yang sering terjadi dan bahkan tidak jarang menimbulkan gejolak dalam kehidupan sosial.

Berbagai upaya yang dilakukan untuk memperlancar pelaksanaan eksekusi jaminan fidusia antara lain dengan melibatkan kepolisian untuk menjamin pelaksanaan eksekusi sesuai dengan keinginan pelaku usaha.

\section{a. Eksekusi Jaminan Fidusia Menurut Perundang-undangan}

Dalam Undang-undang No.42 Tahun 1999 tentang Jaminan Fidusia, mengenai pelaksanaan eksekusi jaminan fidusia diatur dalam ketentuan Bab $\mathrm{V}$ Eksekusi Jaminan Fidusia dalam Pasal 29, Pasal 30, Pasal 31, Pasal 32, Pasal 33, dan Pasal 34.

Pelaksanaan eksekusi jaminan fidusia yang diatur dalam UU No. 42 Tahun 1999 tentang Jaminan Fidusia secara hukum memberikan kewenangan yang cukup besar pagi penerima fidusia. Hal itu dapat dibaca dari pasal-pasal berikut ini:

(1) Apabila debitur atau Pemberi Fidusia cidera janji, eksekusi terhadap benda yang menjadi objek Jaminan Fidusia dapat dilakukan dengan cara: (a) pelaksanaan titel eksekutorial sebagaimana dimaksud dalam Pasal 15 ayat (2) oleh Penerima Fidusia. (b) penjualan benda yang menjadi

${ }^{1}$ Marulak Pardede, dkk. Implementasi Jaminan Fidusia dalam Pemberian Kredit di Indonesia (Laporan Akhir Penelitian Hukum), Badan objek Jaminan Fidusia atas kekuasaan Penerima Fidusia sendiri melalui pelelangan umum serta mengambil pelunasan piutangnya dari hasil penjualan; (c) penjualan di bawah tangan yang dilakukan berdasarkan kesepakatan Pemberi dan Penerima Fidusia jika dengan cara demikian dapat diperoleh harga tertinggi yang menguntungkan para pihak.

(2) Pelaksanaan penjualan sebagaimana dimaksud dalama ayat (1) huruf $\mathrm{c}$ dilakukan setelah lewat waktu 1 (satu) bulan sejak diberitahukan secara tertulis oleh Pemberi dan atau Penerima Fidusia kepada pihakpihak yang berkepentingan dan diumumkan sedikitnya dalam 2 (dua) surat kabar yang tersebar di daerah yang bersangkutan (Pasal 29).

Sebagai wujud kewenangan yang diberikan oleh undang-undang kepada penerima fidusia atau perusahaan pembiayaan, "Pemberi Fidusia wajib menyerahkan benda yang menjadi objek Jaminan Fidusia dalam rangka pelaksanaan eksekusi Jaminan Fidusia (Pasal 31). Oleh karena itu setiap janji yang bertentangan dengan kedua pasal tersebut adalah batal, sesuai ketentuan, "Setiap janji untuk melaksanakan eksekusi terhadap benda yang menjadi objek Jaminan Fidusia dengan cara yang bertentangan dengan ketentuan sebagaimana dimaksud dalam Pasal 29 dan Pasal 31, batal demi hukum" (Pasal 32).

Pelaksanaan eksekusi objek jaminan fidusia selama ini oleh penerima fidusia atau perusahaan pembiayaan (kreditur) dilakukan secara sewenangwenang oleh karena sekalipun tidak serta merta objek jaminan fidusia langsung menjadi milik penerima fidusia.

Pembinaan Hukum Nasional, Departemen Hukum dan Hak Asasi Manusia RI, 2006. Hal. 60. 
Penerima fidusia menguasai penuh seluruh hasil penjualan objek jaminan fidusia meskipun terdapat sisa dari jumlah hutang penerima fidusia (debitur). Padahal dalam UU Jaminan Fidusia diatur, "Setiap janji yang memberi kewenangan kepada Pemberi Fidusia untuk memiliki benda yang menjadi objek Jaminan Fidusia apabila debitor cidera janji, batal demi hukum" (Pasal 33).

Oleh karena itu sebagai realisasi ketentuan tersebut, maka selisih antara piutang penerima fidusia dengan hasil penjualan (pelelangan) yang dilakukan tetap wajib dikembalikan kepada konsumen atau debitur, sesuai ketentuan Pasal 34 UU Jaminan Fidusia yang mengatur: (1) Dalam hal hasil eksekusi melebihi nilai penjaminan, Penerima Fidusia wajib mengembalikan kelebihan tersebut kepada Pemberi Fidusia. (2) Apabila hasil eksekusi tidak mencukupi untuk pelunasan utang, debitor tetap bertanggung jawab atas utang yang belum terbayar.

Peraturan Kapolri No.8 Tahun 2011 tentang Pengamanan Eksekusi Jaminan Fidusia yang mengatur mekanisme pengamanan pelaksanaan eksekusi jaminan fidusia dari tangan pembeli menunjukkan betapa sulitnya pelaksanaan eksekusi objek jaminan fidusia yang seringkali menimbulkan konflik di tengah masyarakat.

Dalam Pasal 2 Peraturan Kapolri No.8 Tahun 2011 tersebut diuraikan mengenai tujuan peraturan itu dikeluarkan adalah: a. Terselenggaranya pelaksanaan eksekusi jaminan fidusia secara aman, tertib, lancar, dan dapat dipertanggungjawabkan; dan b. Terlindunginya keselamatan dan keamanan penerima jaminan fidusia, pemberi jaminan fidusia, dan/atau masyarakat dari perbuatan yang dapat menimbulkan kerugian harta benda dan/atau keselamatan jiwa.
Adapun prinsip-prinsip Peraturan Kapolri No.8 Tahun 2011 tersebut, diatur dalam Pasal 3 meliputi: a. Legalitas, yaitu pelaksanaan pengamanan eksekusi jaminan fidusia harus sesuai dengan ketentuan peraturan perundangundangan; b. Nesesitas, yaitu pengamanan eksekusi jaminan fidusias diberikan berdasarkan penilaian situasi dan kondisi yang dihadapi; c. Proporsional, yaitu pengamanan eksekusi jaminan fidusia dilaksanakan dengan memperhitungkan hakikat ancaman yang dihadapi dan pelibatan kekuatan; dan d. Akuntabilitas, yaitu pelaksanaan pengamanan eskekusi jaminan fidusia dapat dipertanggung-jawabkan.

Mencermati ketentuan tersebut seharusnya eksekusi yang selama ini dilaksanakan pelaku usaha atau perusahaan pembiayaan tidak menggunakan jasa eksternal yang akan menambah beban kepada konsumen dengan meminta biaya penarikan yang sangat tinggi. Di samping itu metode yang digunakan tenaga eksternal tersebut cenderung kurang humanis sehingga seringkali menimbulkan konflik dengan konsumen.

Otoritas Jasa Keuangan (OJK) telah mewajibkan perusahaan pembiayaan yang menangani bidang penagihan agar mengantongi sertifikasi bidang penagihan, dan lembaga yang diberi kewenangan menyelenggarakan sertifikasi tersebut adalah Asosiasi Perusahaan Pembiayaan Indonesia (APPI). Hal ini sesuai dengan ketentuan Pasal 48 Peraturan Otoritas Jasa Keuangan Republik Indonesia No.35/POJK.5/2018, yakni:

(1) PerusahaanPembiayaan dapat melakukan kerja sama dengan pihak lain untuk melakukan fungsi penagihan kepada Debitur.

(2) PerusahaanPembiayaanwajib menuangkan kerjasama dengan pihak lain sebagaimana 
dimaksudpada ayat (1) dalam bentuk perjanjian tertulis bermeterai.

(3) Kerja sama dengan pihak lain sebagaimana dimaksud pada ayat (1) wajib memenuhi ketentuan sebagai berikut: (a) pihak lain tersebut berbentuk badan hukum; (b) pihak lain tersebut memiliki izin dari instansi berwenang; dan (c) pihak lain tersebut memiliki sumber daya manusia yang telah memperoleh sertifikasi di bidang penagihan dari Lembaga Sertifikasi Profesidi bidang pembiayaan.

(4) Perusahaan Pembiayaan wajib bertanggung jawab penuh atas segala dampak yang ditimbulkan dari kerja sama dengan pihak lain sebagaimana dimaksud pada ayat (1).

(5) Perusahaan Pembiayaan wajib melakukan evaluasi secara berkala atas kerjasama dengan pihak lain sebagaimana dimaksud pada ayat (1).

Selanjutnya pihak perusahaan pembiayaan diwajibkan membuat pedoman yang menjadi acuan dalam pelaksanaan eksekusi agunan agar pelaksanaan eksekusi tidak berpotensi menimbulkan gejolak dari debitur yang sering menolak pelaksanaan eksekusi karena akibat penjelasan pemberi fidusia atau perusahaan pembiayaan kepada konsumen yang tidak memadai misalnya mengenai jumlah kewajiban utang yang pasti (sesuai Pasal 50 ayat 4) yang menyebabkan eksekusi dilakukan. Hal ini dapat dibaca pada ketentuan Pasal 49Peraturan Otoritas Jasa Keuangan Republik Indonesia No.35/POJK.5/2018:

(1) Perusahaan Pembiayaan wajib memiliki pedoman internal mengenai eksekusi agunan.

(2) Otoritas Jasa Keuangan berwenang meminta kepada Perusahaan Pembiayaan untuk menyesuaikan pedoman internal mengenai eksekusi agunan.

(3) Perusahaan Pembiayaan wajib menyesuaikan pedoman internal mengenai eksekusi agunan berdasarkan permintaan Otoritas Jasa Keuangan sebagaimana dimaksud pada ayat (2).

Oleh sebab itu, bilamana penerima fidusia memberikan informasi yang memadai dan memuaskan seluruh kewajiban yang pemberi fidusia secara terbuka dan transparan, maka pemberi fidusia (konsumen) akan lebih bijak dalam menerima informasi yang disampaikan kepada konsumen. Untuk itu proses pelaksanaan eksekusi menurut Pasal 50 Peraturan Otoritas Jasa Keuangan Republik Indonesia No.35/POJK.5/2018 diharapkan sesuai kriteria yang sudah ditentukan dalam POJK-RI ini, yakni:

(1) Eksekusi agunanolehPerusahaan Pembiayaan wajib memenuhi ketentuan sebagai berikut: (a) Debitur terbukti wanprestasi; (b) Debitur sudah diberikan surat peringatan; dan (c) Perusahaan Pembiayaan memiliki sertifikat jaminan fidusia, sertifikat hak tanggungan, dan/atau sertifikat hipotek.

(2) Eksekusiagunan sebagaimana dimaksud pada ayat (1) wajib dilaksanakan sesuai dengan ketentuan peraturan perundangundangan yang mengatur masingmasing agunan.

(3) Eksekusi agunan sebagaimana dimaksud pada ayat (1) wajib dituangkan dalam berita acara eksekusi agunan.

(4) Dalam hal terjadi eksekusi agunan, Perusahaan Pembiayaan wajib menjelaskan kepada Debitur informasi mengenai: (a) outstandingpokok terutang; (b) bunga yang terutang; (c) denda yang 
terutang; (d) biaya terkait eksekusi agunan; dan (e) mekanisme penjualan agunan dalam hal Debitur tidak menyelesaikan kewajibannya.

Setelah pelaksanaan eksekusi agunan fidusia oleh pelaku usaha tidak serta merta langsung dilakukan pelelangan oleh penerima fidusia, namun seharusnya tetap berkomunikasi dengan pemberi fidusia. Hal ini sering diabaikan oleh penerima fidusia dengan langsung melakukan pelelangan, sehingga pemberi fidusia kehilangan komunikasi dengan pemberi fidusia. Padahal dalam Pasal 50 yang paling memberatkan bagi pemberi fidusia adalah bilamana objek jaminan sudah dilakukan pelelangan, namun hutangnya belum tercover dari hasil pelelangan, maka hal itu tetap menjadi beban pemberi fidusia untuk membayar, sesuai ketentuan Pasal 51 Peraturan Otoritas Jasa Keuangan Republik Indonesia No.35/POJK.5/2018:

(1) Dalam hal setelah dilaksanakan eksekusi agunan dan Debitur tidak dapat menyelesaikan kewajiban dalam jangka waktu tertentu, Perusahaan Pembiayaan hanya dapat melakukan: (a) penjualan agunan melalui pelelangan umum serta mengambil pelunasan piutangnya dari hasil penjualan; dan/atau (b) penjualan agunan di bawah tangan yang dilakukan berdasarkan kesepakatan harga Perusahaan Pembiayaan dan Debitur sebelum agunan dijual.

(2) Pelaksanaan penjualan sebagaimana dimaksud pada ayat (1) huruf b dilakukan setelah lewat waktu 1 (satu) bulan sejak diberitahukan secara tertulis oleh Perusahaan Pembiayaan kepada Debitur dan diumumkan paling sedikit dalam 2 (dua) surat kabar yang beredar di daerah yang bersangkutan.

Perusahaan pembiayaan yang bertindak sebagai penerima fidusia seharusnya mempunyai keterbukaan mengenai hak-hak pemberi fidusia mengenai sisa hasil penjualan objek jaminan fidusia. Hal ini seringkali diabaikan dan tidak dimuat dalam perjanjian baku yang sudah disiapkan penerima fidusia. Hal ini merupakan itikad buruk penerima fidusia untuk merugikan konsumen. Padahal sesuai ketentuan Pasal 52Peraturan Otoritas Jasa Keuangan Republik Indonesia (POJKRI) No.35/POJK.5/2018, pemberi fidusia wajib mengembalikan sisa penjualan objek jaminan kepada penerima fidusia, yakni: "Perusahaan Pembiayaan wajib mengembalikan uang kelebihan dari hasilpenjualan agunan melalui pelelangan umum sebagaimana dimaksud dalam Pasal 51 ayat (1) huruf a atau penjualan agunan di bawah tangan sebagaimana dimaksud dalam Pasal 51 ayat (1) huruf b kepada Debitur dalam jangka waktu sesuai dengan perjanjian pembiayaan".

\section{b. Eksekusi Jaminan Fidusia Menurut Putusan Mahkamah Konstitusi No.18/PUU-XVII/2019}

Pada tanggal 6 Januari 2020, Majelis Hakim Mahkamah Konstitusi membacakan Putusan Perkara Pengujian Peraturan Perundangan-undangan, yaitu Undang-Undang Nomor 42 Tahun 1999 tentang Jaminan Fidusia (UU Fidusia) terhadap Undang-Undang Dasar Negara Republik Indonesia Tahun 1945 (UUD 1945). Putusan ini "Mengabulkan permohonan para Pemohon untuk sebagian" dan selanjutnya menyatakan bahwa beberapa frasa beserta penjelasannya yang terdapat pada Pasal 15 ayat (2) beserta penjelasannya dan ayat (3) UU Fidusia bertentangan dengan UUD 1945 sepanjang tidak dimaknai sebagaimana tafsir yang diberikan oleh Majelis Hakim Mahkamah Konstitusi yang dimuat dalam Putusan terkait. Frasa-frasa yang dimaksud yaitu, 
pertama, frasa "kekuatan eksekutorial" dan "sama dengan putusan pengadilan yang berkekuatan hukum tetap" (beserta penjelasannya) yang terdapat pada Pasal 15 ayat (2) dan kedua, yaitu frasa "cidera janji" yang terdapat pada Pasal 15 ayat (3) UU Fidusia. ${ }^{2}$

Setelah Putusan Mahkamah Konstitusi Nomor 18/PUU-XVII/2019 terhadap Pasal 15 ayat (2) dan ayat (3) Undang-undang Jaminan Fidusia, khususnya mengenai Wanprestasi dan Eksekusi Jaminan Fidusia menjadi berubah penafsirannya. Setelah Putusan MK, wanprestasi dan eksekusi harus ditafsirkan berbeda. Yakni wanprestasi harus disepakati lebih dahulu, apabila terjadi cidera janji. Dan eksekusi harus ada pernyataan sukarela dari debitur atau melalui putusan pengadilan.

Putusan Mahkamah Konstitusi Nomor 18/PUU-XVII/2019 menyatakan bahwa Pasal 15 ayat (2) dan (3) serta Penjelasan Pasal 15 ayat (2) Undangundang Nomor 42 Tahun 1999 tentang Jaminan Fidusia berlaku secara inkonstitusional bersyarat (conditionally unconstitusional). Artinya, ketentuan tersebut harus dianggap bertentangan dengan UUD 1945 (inkonstitusional) jika syarat yang ditetapkan MK tidak dipenuhi sesuai dengan amar putusan. Ada 3 (tiga) syarat yang kemudian diberikan oleh MK yakni.

Pertama, terkait Pasal 15 ayat (2) diberikan syarat bahwa "terhadap jaminan fidusia yang tidak ada kesepakatan tentang cidera janji (wanprestasi) dan debitur keberatan menyerahkan secara sukarela objek yang menjadi jaminan fidusia, maka segala mekanisme dan prosedur hukum dalam pelaksanaan eksekusi Sertifikat Jaminan Fidusia harus dilakukan dan berlaku sama dengan pelaksanaan eksekusi putusan

${ }^{2}$ Putusan Mahkamah Konstitusi Nomor 18/PUUXVII/2019: Apa Implikasinya Bagi Proses Bisnis Lelang? Diunduh tanggal 19 Desember 2020. pengadilan yang telah berkekuatan hukum tetap".

Kedua, terhadap Pasal 15 ayat (3) diberikan syarat bahwa "adanya cidera janji tidak ditentukan secara sepihak oleh kreditur melainkan atas dasar kesepakatan antara kreditur dengan debitur atau atas dasar upaya hukum yang menentukan telah terjadinya cidera janji”.

Ketiga, terkait Penjelasan Pasal 15 ayat (2) diberikan syarat bahwa "terhadap jaminan fidusia yang tidak ada kesepakatan tentang cidera janji dan debitur keberatan menyerahkan secara sukarela objek yang menjadi jaminan fidusia, maka segala mekanisme dan prosedur hukum dalam pelaksanaan eksekusi Sertifikat Jaminan Fidusia harus dilakukan dan berlaku sama dengan pelaksanaan eksekusi putusan pengadilan yang telah berkekuatan hukum tetap". 3

Peneliti menanyakan kesiapan perusahaan pembiayaan PT. BCA Finance Cabang Makassar (diwakili Branch Operation Head) menjelaskan bahwa kesiapan perusahaan untuk menyesuaikan putusan MK tersebut sedang dilakukan langkah-langkah konkret, dan untuk itu dibutuhkan waktu.

Sementara itu kuasa hukum PT. Maybank Finance yang telah mengupayakan pelaksanaan Putusan MK tersebut menemukan kendala dalam proses eksekusi objek jaminan fidusia. Pada saat wawancara antara lain dijelaskan kepada peneliti bahwa pelaksanaan eksekusi yang dimuat dalam Putusan MK masih menyulitkan dan membutuhkan pengaturan yang lebih konkret. Pelaksanaan eksekusi jaminan fidusia oleh pengadilan bukanlah hal yang mudah seperti layaknya objek jaminan hak tanggungan yang berupa benda tidak bergerak atau benda tetap. Ketika pelaksanaan eksekusi dilakukan

${ }^{3}$ Implikasi Putusan MK. No.18/PUU-

XVII/2019, diunduh tanggal 19 Desember 2020. 
oleh pengadilan dengan mengacu pada ketentuan yang berlaku pada umumnya terhadap pelaksanaan putusan pengadilan atau eksekusi hak tanggungan dan sebagainya, maka terdapat kesulitan bilamana konsumen mempunyai itikad buruk atau tidak kooperatif.

Kesulitan yang dihadapi dalam hal ini adalah ketika pengadilan melakukan teguran (aanmaaning) terhadap konsumen bahwa objek jaminan fidusia akan dieksekusi pada hari dan jam yang sudah diagendakan oleh pengadilan, maka kemungkinan objek jaminan fidusia disembunyikan atau berbagai upaya yang dapat dilakukan konsumen untuk menghindari eksekusi atas objek tersebut.

Meskipun demikian dalam praktik terjadi peningkatan permohonan eksekusi jaminan fidusia di pengadilan. Hal ini sesuai wawancara dengan petugas pendaftaran gugatan dan permohonan pada Pengadilan Negeri Makassar, setelah lahirnya Putusan MK No.18/PUU-XVII/2019, terjadi peningkatan jumlah permohonan eksekusi objek jaminan fidusia yang diajukan pelaku usaha atau penerima fidusia.

Terkait dengan lahirnya Putusan Mahkamah Konstitusi tersebut, menimbulkan perbincangan yang cukup meluas terkait berubahnya kaidah pelaksanaan eksekusi. Dalam suatu kegiatan pada Kamis 27 Febrauri 2020, di Grandia Hotel Jalan Cihampelas No. 8082 Kota Bandung, berlangsung kajian Putusan Mahkamah Konstitusi Nomor 18/PUU-XVII/2019 berkenaan dengan Eksekusi Jaminan Fidusia. Kegiatan tersebut diselenggarakan oleh Pengurus Wilayah Jawa Barat, Ikatan Notaris Indonesia (Pengwil Jabar INI) bekerjasama dengan Ikatan Keluarga Alumni Kenotariatan, Universitas Padjdjaran (Ikano Unpad) serta Fakultas Hukum Universitas Padjdjaran (FH
Unpad) dengan menghadirkan tiga pembicara, Badar Baraba (Notaris PPAT Senior), Isis Ikhwansyah (Direktur Tata Kelola, Legal dan Komunikasi Unpad), Suhartoyo (Hakim Mahkamah Konstitusi). Dalam kajiannya ketiga pembicara membahas tema besar terkait "Kajian Mengenai Kepastian Hukum dan Perlindungan Hukum dalam Penjaminan Fidusia Pasca Putusan MK Nomor 18/PUU-XVII/2019. ${ }^{4}$

Dalam kegiatan tersebut Badar Baraba menjelaskan, hal-hal yang perlu dilakukan oleh Notaris dalam membuat perjanjian Jaminan Fidusia adalah mengatur agar diperoleh keseimbangan, kepastian dan keadilan bagi Kreditur, Debitor dan pihak-pihak terkait. Jaminan Fidusia wajib mewujudkan perlindungan hukum baik kepastian hukum maupun keadilan bagi pihak-pihak atau subjek yang dimuat dalam suatu perjanjian fidusia dan objek jaminan dalam perjanjian Jaminan Fidusia.

Menurut Badar, "Putusan MK tersebut tentu menimbulkan perbedaan persepsi, terutama pada pemahaman mengenai kekuatan titel eksekutorial yang selama ini dipahami. Putusan MK tersebut menjadikan titel eksekutorial tidak serta merta berkekuatan sebagaimana putusan pengadilan yang telah memiliki kekuatan hukum yang mengikat dalam kondisi tertentu sebagaimana ditegaskan dalam Amar Putusan,"

Selain itu menurut Badar, "dalam Undang-undang Jaminan Fidusia tidak mengatur kapan cidera janji itu terjadi dan siapa yang berhak menentukan cidera janji, karena sesungguhnya Jaminan Fidusia adalah Lembaga Jaminan dan bukan lembaga peralihan hak, maka apabila kita amati ketentuan yang terdapat dalam Pasal 33 UndangundangJaminan Fidusia, maka Penerima

${ }^{4}$ diunduh tanggal 19 Desember 2020 
Fidusia tidak dapat memiliki benda yang menjadi objek Jaminan Fidusia demikian pula dalam hal yang menyangkut kelebihan eksekusi".

Notaris yang akan membuat akta Jaminan Fidusia perlu memahami dan mengatur dalam perjanjian yang dibuat antara lain: kesepakatan tentang pengertian dan kapan cidera janji itu terjadi, bagaimana mekanisme dan tata cara penyerahan secara sukarela terhadap benda jaminan fidusia, bagaimana eksekusi jaminan fidusia, bagaimana tata cara dan mekanisme upaya paksa yang dapat dilakukan dalam hal Pemberi Fidusia Cidera janji.

Solusi jangka pendek pasca putusan MK, diusulkan agar; Pertama, Notaris pembuat akta jaminan fidusia dalam membuat akta perlu memuat klausul tersebut. Kedua, Mahkamah Agung perlu membuat aturan tentang mekanisme dan tata cara eksekusi jaminan fidusia secara sederhana, cepat, mudah dan murah. Dan ketiga, perlu diadakan perubahan terhadap Undangundang Jaminan Fidusia yang mengatur eksekusi jaminan fidusia dimana dalam hal pemberi fidusia bersedia menyerahkan benda atau barang jaminan fidusia secara sukarela, dan dalam hal pemberi fidusia tidak bersedia menyerahkan benda atau barang jaminan secara sukarela.

Sebelum lahirnya putusan Mahkamah, Pasal 15 Ayat (2) dan Ayat (3) menyatakan bahwa sertifikat fidusia mempunyai titel eksekutorial yang memberikan arti bahwa putusan dapat dilaksanakan sebagaimana sebuah putusan pengadilan yang mempunyai kekuatan hukum tetap tanpa melalui prosedur atau tata-cara eksekusi sebagaimana pelaksanaan eksekusi yang dimaksud kan dalam Pasal 196 HIR atau Pasal 208 RBg.

Suhartoyo seorang hakim Mahkamah Konstitusi menjelaskan eksekusi dapat dilakukan sendiri oleh penerima fidusia. Ketentuan Pasal 196 HIR atau Pasal 208 RBg selengkapnya adalah: "Jika pihak yang dikalahkan tidak mau atau lalai untuk memenuhi isi keputusan itu dengan damai, maka fihak yang menang memasukkan permintaan, baik dengan lisan, maupun dengan surat, kepada ketua pengadilan negeri yang tersebut pada ayat pertama Pasal 195, buat menjalankan keputusan itu ketua menyuruh memanggil pihak yang dikalahkan itu serta memperingatkan, supaya ia memenuhi keputusan itu di dalam tempo yang ditentukan oleh ketua, yang selama-lamanya delapan hari".

Suhartoyo menjelaskan kewenangan eksklusif yang dimiliki oleh penerima fidusia (kreditur), tetap dapat melekat sepanjang tidak terdapat permasalahan dengan kepastian waktu perihal kapan pemberi hak fidusia (debitur) telah "cidera janji" (wanprestasi) dan debitur secara suka rela menyerahkan benda yang menjadi objek dari perjanjian fidusia kepada kreditur untuk dilakukan penjualan sendiri. Dengan kata lain, dalam hal ini, pemberi fidusia (debitur) mengakui bahwa dirinya telah "cidera janji" sehingga tidak ada alasan untuk tidak menyerahkan benda yang menjadi objek perjanjian fidusia kepada penerima fidusia (kreditur) guna dilakukan penjualan sendiri oleh penerima fidusia (kreditur).

Oleh karenanya kewenangan sepenuhnya bagi penerima fidusia (kreditur) untuk dapat melakukan eksekusi sendiri (parate eksekusi) terhadap benda jaminan fidusia. Namun, apabila yang terjadi sebaliknya, di mana pemberi hak fidusia (debitur) tidak mengakui adanya "cidera janji" (wanprestasi) dan keberatan untuk menyerahkan secara sukarela benda yang menjadi objek dalam perjanjian fidusia, maka penerima fidusia (kreditur) tidak boleh melakukan eksekusi sendiri 
melainkan harus mengajukan permohonan pelaksanaan eksekusi kepada pengadilan negeri. Dengan demikian hak konstitusionalitas pemberi hak fidusia (debitur) dan penerima hak fidusia (kreditur) terlindungi secara seimbang.

Suhartoyo memberikan kesimpulan: pertama, bahwa hak eksekutorial yang dimiliki oleh penerima hak fidusia serta merta dalam sertifikat jaminan fidusia yang dianggap sebagai putusan pengadilan yang berkekuatan hukum tetap telah menimbulkan ketidakpastian hukum dan menjadikan posisi antara debitur dan kreditur timpang atau tidak sejajar. Kedua, sebelum adanya Putusan Mahkamah Konstitusi No. 18/PUUXVII/2019, terdapat ketidakpastian hukum terkait frasa "cidera janji" dalam Pasal 15 ayat (2) dan ayat (3) terkait kapan debitur dianggap cidera janji. Dan ketiga, Ketentuan terkait cidera janji sudah ditentukan di awal perjanjian. Keempat, hak eksekutorial penerima fidusia tidak ditiadakan sepanjang debitur sukarela menyerahkan objek fidusia. Apabila debitur menyetujui adanya cidera janji dan secara sukarela menyerahkan objek jaminan fidusia, maka kreditur dapat melakukan hak eksekutorialnya. Kelima, jika debitur tidak menyetujui adanya cidera janji dan tidak secara sukarela menyerahkan objek fidusia maka kreditur harus mengajukan permohonan ke pengadilan agar eksekusi dapat dilakukan dengan berpedoman pada Pasal 196 HIR atau Pasal 208 RBg.

\section{PENUTUP}

Perjanjian baku yang disiapkan pelaku usaha yang menjadi sumber hubungan hukum antara pelaku usaha dengan konsumen dalam pembiayaan konsumen belum memberikan perlindungan hukum sesuai harapan. Dan itulah salah satu tujuan dibuatnya perjanjian baku adalah untuk mengendalikan konsumen dari segala hal-hal yang berpotensi merugikan pelaku usaha. Berbagai klausula yang dibuat pelaku usaha bertentangan dengan ketentuan Undang-undang No. 8 Tahun 1999 tentang Perlindungan Konsumen, Undang-undang No. 21 Tahun 2011 tentang Otoritas Jasa Keuangan, Peraturan OJK RI No. 35/POJK.5/2018 tentang Penyelenggaraan Usaha Perusahaan Pembiayaan, bahkan terjadi pengabaian ketentuan tersebut untuk mengelabui konsumen.

Pelaksanaan eksekusi objek jaminan fidusia sebelum Putusan MK No. 18/PUU-XVII/2019 yang selama ini dilaksanakan pelaku usaha jika konsumen wanprestasi adalah dengan menggunakan jasa eksternal dan hal itu menyalahi ketentuan Peraturan Kapolri No.8 Tahun 2008, UU Jaminan Fidusia dan Peraturan OJK RI No.35/POJK.5/2018 tentang Penyelenggaraan Usaha Perusahaan Pembiayaan. Setelah Putusan MK No. 18/PUU-XVII/2019, pelaksanaan eksekusi objek jaminan fidusia oleh pelaku usaha belum dilaksanakan secara maksimal, bahkan masih melakukan langkah-langkah adaptasi. Selain itu pelaku usaha meskipun berusaha melaksanakan sesuai Putusan MK tersebut namun di lapangan terjadi kesulitan oleh karena objek jaminan fidusia dalam perjanjian pembiayaan adalah benda bergerak, sehingga setiap saat dapat disembunyikan konsumen yang beritikad buruk dan tidak kooperatif. Namun terjadi peningkatan permohonan eksekusi jaminan fidusia di Pengadilan Negeri Makassar setelah Putusan MK.

Perjanjian yang menjadi sumber perikatan antara pelaku usaha dengan konsumen dalam perjanjian pembiayaan seharusnya disesuaikan dengan berbagai ketentuan yang berlaku dan tetap memperhatikan kepentingan konsumen. 
Diperlukan keterbukaan pelaku usaha untuk menjelaskan hak-hak pemberi fidusia jika terjadi pelelangan objek jamian fidusia, maka sisa penjualan menjadi hak pemberi fidusia (konsumen). Seharusnya pelaku usaha lebih mengutamakan kepentingan konsumen atau penerima kredit dalam proses eksekusi objek jaminan fidusia setelah terbitnya Putusan MK No.18/PUUXVII/2019 yang lebih bersifat humanis dan pelaku usaha selayaknya menempuh upaya eksekusi melalui pengadilan jika tidak terjadi kesepakatan mengenai terjadinya wanprestasi atau cidera janji antara pemberi fidusia dan penerima fidusia. Selain itu diperlukan aturan yang khusus dan konkret mengenai eksekusi objek jaminan fidusia dalam perjanjian pembiayaan konsumen berupa benda bergerak yang berbeda dengan eksekusi atas objek hak tanggungan yang objeknya benda tetap.

\section{DAFTAR PUSTAKA}

Alfian, 2017, Eksekusi Jaminan Fidusia Dalam Kontrak Pembiayaan Konsumen Di Kota Palu, Jurnal Katalogis Volume 5 Nomor 1 Januari 2017

Cortes, P. 2011. Online Dispute Resolution for Consumers in the European Union. Rountledge Research in IT and E-Commerce Law. London and New York.

Endipraja, F.T. 2016. Hukum Perlindungan Konsumen, Setara press. Malang.

Fuady, M. 2006. Hukum Tentang Pembiayaan, PT. Citra Aditya Bakti, Bandung.

Harahap, Y. 2006. Ruang Lingkup Permasalahan Eksekusi Bidang Perdata, Edisi Kedua. Sinar Grafika. Jakarta.
Implikasi Putusan MK. No.18/PUUXVII/2019, diunduh tanggal 19 Desember 2020.

Komnas LKPI, diunduh tanggal 26 Februari 2020.

Marulak Pardede, dkk. 2006. Implementasi Jaminan Fidusia dalam Pemberian Kredit di Indonesia (Laporan Akhir Penelitian Hukum), Badan Pembinaan Hukum Nasional, Departemen Hukum dan Hak Asasi Manusia RI.

Miru, A. dan Sutarman Yodo. 2004. Hukum Perlindungan Konsumen. Raja Grafindo Persada. Jakarta.

- 2011. Hukum Perlindungan Bagi Konsumen di Indonesia, RajaGrafindo Persada. Jakarta.

Nasution, Az. 2007. Hukum Perlindungan Konsumen, Sutau Pengantar. Diadit Media. Jakarta.

Nasution, B.J. 2008. Metode Penelitian Ilmu Hukum. Mandar Maju, Bandung.

Ni Kadek Candika Prawani, Nyoman Mas Ariyani, 2017, Perlindungan Hukum Leassor Terhadap Obyek Leasing Apabila Lessse Wanprestasi, Vol. 06, No. 06, Jurnal Fakultas Hukum Universitas Udayana.

Ni Nyoman Ayu Adnyaswari, Suatra Putrawan, 2018, Kekuatan Hukum Akta Jaminan Fidusia Yang Tidak Didaftarkan, Vol. 6, No. 12, Jurnal Fakultas Hukum Universitas Udayana.

Ni Putu Theresa Putri Nusantara, 2018, Eksekusi dan Pendaftaran Objek Jaminan Fidusia Berdasarkan Undang-Undang Nomor 42 Tahun 1999 Tentang Jaminan Fidusia, Vol. 02, No. 02, Jurnal Fakultas Hukum Universitas Udayana. 
Putusan Mahkamah Konstitusi Nomor 18/PUU-XVII/2019: Apa Implikasinya Bagi Proses Bisnis Lelang? Diunduh tanggal 19 Desember 2020.

Rufaidah, K. K. dan Rian Sacipto, sesuai tulisan berjudul, Tinjauan Hukum Terhadap Eksekusi Objek Jaminan Fidusia Tanpa Titel Eksekutorial yang Sah, dalam Refleksi Hukum, Jurnal Ilmu Hukum, FH. Universitas Kristen Satya Wacana, Volume 4 No. 1, Oktober 2019, hlm. 22.

Satrio, J. 1993. Hukum Jaminan, Hak-hak Jaminan Kebendaan. PT. Citra Aditya Bakti, Bandung. 1997. Hukum Jaminan, Hak Jaminan Kebendaan, Hak Tanggungan. Citra Aditya Bakti, Bandung.

Shidarta. 2000. Hukum Perlindungan Konsumen Indonesia, PT. Grasindo, Jakarta.

Soenandar, T. dkk. 2016. Kompilasi Hukum Perikatan. PT. Citra Aditya Bakti, Bandung.

Sofie, Y. 2008. Kapita Selekta Hukum Perlindungan Konsumen. Citra Aditya Bakti, Bandung.

Sofwan, S. S. M. 1980. Hukum Jaminan di Indonesia, Pokok-pokok Hukum Jaminan, dan Jaminan Perorangan. BPHN, Jakarta.

Subekti. 2001. Pokok-pokok Hukum Perdata, PT. Intermasa, Jakarta.

Sunaryo. Hukum Lembaga Pembiayaan, Sinar Grafika, Jakarta, 2009 hlm 95, dalam tulisan berjudul "Eksekusi Terhadap Benda Jaminan Fidusia yang tidak didaftarkan pada PT. Capella Multidana", dalam Jurnal JOM Fakultas Hukum Volume III Nomor 1 Februari 2016, hlm. 2.

Wijaya, G dan Ahmad Yani. 2000, Seri Hukum Bisnis, Jaminan Fidusia, RajaGrafindo Persada, Jakarta. 